\title{
ASTOLFO MARQUES E AS FESTAS POPULARES MARANHENSES
}

\author{
Matheus Gato de Jesus*
}

$\mathrm{R}$

aul Astolfo Marques teve uma vida curta, laboriosa e produtiva. Entretanto, tal como diversos personagens negros da história brasileira, é difícil acompanhar em detalhes sua biografia, especialmente no que tange às suas origens. O escritor nasceu em $14 \mathrm{de}$ abril de 1876, apenas cinco anos após a Lei do Ventre Livre, em São Luís do Maranhão. Faleceu na mesma cidade aos 42 anos, em 28 de maio de 1918, morto por uma tuberculose contra a qual lutava, pelo menos, desde 1915.

A produção intelectual conhecida do autor envolve estudos bibliográficos, traduções, contos, crônicas, estudos folclóricos, um romance, afora sua extensa colaboração para os principais jornais e revistas de São Luís como $O$ Diário do Maranhão, A Pacotilha, Diário Oficial, $O$ Jornal, Boletim dos Novos, A Revista do Norte e Revista da Associação Comercial. O escritor também consta entre os fundadores das mais importantes agremiações literárias de seu tempo como a Oficina dos Novos (1900) e a Academia Maranhense de Letras (1908). Seus principais trabalhos publicados são: a tradução do francês para o português do romance Por amor, de Paul Bertnay (1901); a coletânea de contos intitulada $A$ vida maranhense (1905); o relato de viagem De S. Luiz a

Doutorando em Sociologia na Universidade de São Paulo. E-mail: matheusgatodejesus@gmail.com 
Therezina (1906); a peça teatral O Maranhão por dentro (1907); a coletânea de contos Natal (1908); a biografia O Dr. Luiz Domingues (1910); o romance A nova aurora (1913).

Diferentemente da trajetória de parte significativa dos intelectuais de origem pobre na Primeira República (1889-1930), Astolfo Marques não contou, em sua meninice e juventude, pelo que se conhece, com a ajuda de um "padrinho" que lhe custeasse os estudos e auxiliasse sua família. Não se registra sequer o nome de seu pai nas notas e resenhas escritas sobre o contista. A mãe, sim, é citada. ${ }^{1}$ Delfina Maria da Conceição Marques era uma cafuza livre que tinha por ofício trabalhos domésticos como lavadeira e passadeira de roupas. Ao contrário do filho, morreu idosa, aos 69 anos de idade em 1915. ${ }^{2}$ A nota de falecimento de uma de suas filhas, Maria dos Remédios Marques, publicada em 1894, revela que o escritor teve seis irmãos: Alexandre da S. Cruz Marques, Percilia Filomena Marques, Mathilde Edmunda Marques, José Jacinto Marques e a mencionada Maria dos Remédios. ${ }^{3}$ Portanto, o núcleo familiar de Astolfo Marques pertence ao quadro das famílias negras livres que conviveram com a escravidão, predominantemente femininas e chefiadas por mulheres.

O crítico literário Antonio de Oliveira destaca, com base na entrevista que o próprio escritor concedeu sobre sua trajetória ao jornal Anais, de 3 de novembro de 1910, documento hoje perdido, que Astolfo Marques, quando menino, trabalhava ajudando sua mãe na entrega da roupa lavada e fazia outros serviços de "moleque" como levar e trazer recados. Nessa mesma entrevista, o autor declarara ter aprendido a ler sozinho. Uma habilidade preciosa, em vista da alta taxa de analfabetismo da população negra e pobre em geral, e decisiva em sua carreira.

Em 1896, Astolfo Marques, com cerca de 20 anos de idade, conseguiu o emprego de servente na Biblioteca Pública de São Luís, um dos principais espaços de sociabilidade intelectual e literária da cidade

\footnotetext{
Humberto de Campos, Memórias inacabadas, Rio de Janeiro, 1935, p.66; Domingos Vieira Filho, "Os escritores maranhenses", Revista do Maranhão, v. 1, n. 6 (1951) p. 5; Antonio de Oliveira, "O centenário de um contista maranhense", O Estado do Maranhão, 10/03/1976. p.7. A Pacotilha, 05/04/1915, p. 3.

A Pacotilha, 13/07/1894, p. 1.
} 
naquele período. Dois anos depois, foi promovido a auxiliar do diretor dessa mesma instituição. A promoção era fruto da sua celebrada dedicação aos trabalhos e aos livros. Um ano antes de sua promoção, encontra-se seu nome, na coluna "Exames Gerais" publicada no jornal $A$ Pacotilha (17 e 23 de dezembro 1897, p. 3), entre os "aprovados simplesmente" nas provas de Aritmética, Geometria e Trigonometria. É revelador que dez anos depois (28 de outubro de 1907), o amanuense apareça novamente na mesma coluna, sendo aprovado com louvor e distinção em História Universal e do Brasil. Tamanho hiato é indicativo da pouca mobilidade educacional do secretário e da necessidade de priorizar o trabalho em relação aos estudos.

Marques trabalhou na Biblioteca Pública de São de Luís até o fim da primeira década do século XX. No capítulo "Biblioteca" do relatório governamental de 1900, pode-se ler, no item pessoal: "Continuam a servir nos cargos de Auxiliares do Diretor os cidadãos Francisco Serapião Serra e Raul Astolfo Marques, dos quais só vos posso dizer bem, pela forma correta com que desempenham os seus deveres". ${ }^{4} E$ dessa época a conhecida passagem de Humberto de Campos em suas Memórias inacabadas, na qual narra o período em que era balconista de uma vivenda nas imediações da Biblioteca Pública:

Uma figura houve entretanto, no Olimpo, que permitiu minha aproximação. Foi Raul Astolfo Marques, que se tornou conhecido, mais tarde, nas letras regionais, como Astolfo Marques, unicamente. Era homem de cor, de tez escura e embaciada, como a dos negros que sofrem do fígado. De estatura mediana, a fronte larga e fugidia, boca enorme e bigode ralo, possuía dentes enormes e brancos, que fazia aparecer a cada instante, sob a beiçorra da raça. Era amanuense da Biblioteca, mas desempenhava todos os misteres de servente: varria o salão, espanava as estantes, etiquetava os livros, enchia o filtro, molhava uma planta que havia à porta, e atravessava duas, três vezes, diariamente, a rua, para ir buscar na "Casa Transmontana", um refresco para Fran Paxeco, Francisco Serra ou Antônio Lobo. Era, segundo me disseram, filho de uma preta, lavadeira e engomadeira. E a isso devia ele, talvez, a alegria de

\footnotetext{
4 Mensagem Apresentada ao Congresso do Estado Pelo Exmo. Sr. Governador Dr. João Gualberto
} Torreão da Costa, 13/02/1901, Anexos, Biblioteca, p. 42. 
exibir, pondo em destaque o seu terno de casimira azul-marinho, cuidadosamente passado a ferro, os mais duros e lustrosos colarinhos do Maranhão.

Humilde e obscuro, mas infatigável no estudo e no trabalho, Astolfo Marques fez-se de tal modo indispensável aos homens brancos a quem servia, que, na organização da "Oficina dos Novos", eles se viram forçados a dar-lhe um lugar a seu lado. ${ }^{5}$

As ambiguidades das funções de Astolfo Marques em seu ambiente de trabalho, nas fronteiras entre um serviço manual e um trabalho que demandava as competências do letramento, são reveladoras das condições de subalternidade de um homem cujo corpo deslizava entre os significados da recente "liberdade dos negros". ${ }^{6}$ Nas palavras de Humberto de Campos, não temos apenas a descrição de Astolfo Marques, mas dimensões do espaço simbólico em que viveu. A posição do escritor como subalterno é qualificada não apenas pelo caráter dos trabalhos de baixo escalão que desempenhava - varrer salão, espanar estantes, molhar plantas, ir duas ou três vezes pegar sucos para seus patrões - mas também sociorracialmente - era "filho de uma preta, lavadeira e engomadeira" que servia aos brancos. A interpretação negativa de sua corporalidade negra ("tez escura e embaciada", "beiçorra da raça") é que confere inteligibilidade à baixa posição social do autor frente aos demais homens de letras do seu tempo. Essa caricatura francamente racista elaborada por Humberto de Campos, com o detalhe da menção à "boca enorme" e aos "dentes enormes", é reveladora do quão exótico lhe parecia aquele perfil querer figurar "no Olimpo" das letras regionais.

Mas assim foi. O trabalho do escritor como contínuo e, depois, auxiliar de direção da Biblioteca Pública de São Luís, principal instituição pública a permitir a constituição de redes de sociabilidade mediadas pelo exercício da cultura letrada, ofereceu condições para que Raul Astolfo Marques pudesse acionar um conjunto de relações de apadrinhamento, favor e clientela, capazes de converter suas ambições profissionais e intelectuais numa carreira exitosa para os padrões regionais.

Campos, Memórias inacabadas, p. 66.

Wlamyra Albuquerque, "Conserve-se a palavra senhor: abolição, racialização e a cidadania dos homens de cor"”, <www.africanos.eu/ceaup/uploads/WP_2008_05>, acessado 20/01/2013. 
Some-se a esse aspecto o fato de o literato desenvolver um projeto intelectual afinado com as necessidades de legitimação simbólica da elite política local, cujo exemplo máximo é a pequena biografia $O \mathrm{Dr}$. Luiz Domingues (1910), do governador do Maranhão (1910-1914), publicada oportunamente como parte do cerimonial de posse do referido mandatário estadual.

Naquele mesmo ano, o governador Luiz Domingues nomeou-o, interinamente, secretário da Instrução Pública e do Liceu Maranhense, cargo em que permaneceu até outubro de 1911. O coronel Frederico Figueira, vice-governador da gestão (1910-1914), nomeou-o como oficial da Secretaria de Governo. Quando esse órgão se extinguiu, em 1915, Astolfo Marques foi realocado na posição de amanuense para a Secretaria do Interior. Em 1918, provavelmente por motivo de saúde, o escritor teve a aposentadoria decretada com todos os seus vencimentos concedidos, na condição de chefe da Segunda Sessão da Secretaria do Interior. ${ }^{7}$

Esse percurso de "moleque" negro livre nos tempos do Império e da escravidão para funcionário público no período da República oligárquica conformou sua obra, na qual se incluem vários contos e crônicas que só vieram à luz nos jornais maranhenses das primeiras décadas do século passado, em dois projetos intelectuais distintos e entrelaçados: a) a elaboração da história intelectual da elite maranhense, sedenta de status e valorização simbólica no instante em que a configuração das relações de poder na Primeira República (1889-1930) assentou seu lócus periférico de atuação política na vida nacional; b) a investigação literária, histórica e folclórica dos hábitos e costumes do povo maranhense, com ênfase nas condições sociais da população negra e pobre no meio urbano de São Luís. Ambas as vertentes afinadas com a ideologia regionalista que grassava à época.

É dessa imersão na cultura popular maranhense, que Astolfo Marques conhecia de perto - cultura prática de negros e mulatos livres antes da abolição, ganhadeiras, ex-escravos, peixeiras, caixeiros portu-

\footnotetext{
Durante a segunda década do século XX, Astolfo Marques exerceu ainda os cargos de diretor da Imprensa Oficial, amanuense da Associação Comercial do Maranhão e secretário da Escola de Comércio.
} 
gueses, operárias de fábricas têxteis —, que se sobressai a contribuição intelectual do escritor negro. No romance $A$ nova aurora, descreve o fuzilamento de "libertos monarquistas" em 17 de novembro de 1889, reação violenta da ordem ao protesto daqueles que viram na deposição da Princesa Isabel uma ameaça à liberdade conquistada na abolição. ${ }^{8}$ Aliás, o tema das frustrações da população negra com a promessa da igualdade aventada na Proclamação da República é um assunto dileto de sua obra ficcional, presente em contos como "Abnegação" (1901), "A última sessão" (1903), "O discurso do Fabrício" (1903), "A opinião da Euzébia" (1904), "De coroa e barrete" (1908) e "Reis republicanos" (1916). ${ }^{9}$ Textos que ressaltam a incapacidade política da então novíssima república brasileira de incorporar social e culturalmente o povo, enquanto categoria política da nação tornada possível com o fim da escravidão. Os escritos e investigações do autor sobre cultura popular expressam sua entrega intelectual e pessoal a esta alternativa: a descoberta, construção e invenção deste novo sujeito político. "Astolfo Marques [...] Anda por entre os nossos costumes de Kodak na mão e apanha, ridículo a ridículo, hábito por hábito, minúcia por minúcia, com uma exatidão de objetiva cara. Não é um homem, é uma máquina fotográfica". ${ }^{10}$

As palavras do escritor Viriato Corrêa ressoam nos seus contos, onde podemos encontrar descrições e criações minuciosas em torno de costumes e festejos desaparecidos como o cordão de carnaval da Cana Verde, feito de personagens e fantasias como o "Manuel da Balaiada", trazendo à rua o imaginário da insurreição e da revolta marcada pela guerra civil da Balaiada (1839-1941). ${ }^{11}$ Também se faz presente a alegria dos "pagodes", termo que o autor utiliza para descrever o batidinho, espécie de samba típico maranhense que fazia sucesso nos arrabaldes crioulizados de São Luís. ${ }^{12}$

\footnotetext{
8 Matheus Gato de Jesus, "Negro, porém republicano" (Dissertação de Mestrado, Universidade de São Paulo, 2010); Josué Montello, "Um ilustre desconhecido". Janela de Mirante, São Luís: Sioge, 1993.

9 Ver Matheus Gato de Jesus, "Tempo e melancolia: república, modernidade e cidadania negra nos contos de Astolfo Marques (1876-1918)", Lua Nova, n. 85 (2012), pp. 133-185.

${ }^{10}$ A Pacotilha, 12/04/1911, p. 2.

11 Astolfo Marques, "De coroa e barrete", A Pacotilha, 02/03/1908, p. 1-2.

12 Astolfo Marques, "O Batidinho". A vida maranhense, São Luis: Tipografia Frias, 1905.
} 
O ensaio "A festa de S. Benedicto" pertence a esse universo de interesses. O texto foi publicado pela primeira vez no jornal Diário do Maranhão em três partes nos dias 02, 04, 05 de abril de 1910. Trazia, logo abaixo do título, uma indicação entre parênteses: "Capítulo de um livro em preparação - AS FESTAS POPULARES MARANHENSES". Um projeto de fôlego com vistas a documentar todas as principais manifestações folclóricas da região no início do século XX.

Entretanto, o livro completo jamais foi encontrado. No principal necrológio do escritor, Fran Paxeco (1874-1952), um de seus confrades na Academia Maranhense de Letras, ao mencionar os trabalhos inéditos de Astolfo Marques à data de sua morte, afirma pesarosamente:

Tinha prontas mais duas séries de contos, um livro sobre as festas populares do estado e a Seleta maranhense, em cuja organização se empenhou, desde 1901 até falecer. [...] Esse compacto manuscrito, o dos contos e o das festas populares submergiram-se. ${ }^{13}$

Nesse sentido, o provável capítulo "A festa de S. Benedicto", que ora vem a público, esquecido por mais de um século por entre os jornais antigos de São Luís, é o único documento que nos permite remontar o desenho original de As festas populares maranhenses. O material ajuda a iluminar a "lacuna" existente na pesquisa folclórica regional entre os trabalhos de Celso Magalhães, publicados nos anos 1870, até os trabalhos de Antonio Lopes sobre o romanceiro maranhense nos anos $1940 .{ }^{14}$ Vale acrescentar que o texto também abre portas para compreender como, bem antes da Revolução de 1930, houve fissuras importantes na repre-

\footnotetext{
13 A Pacotilha, 28/06/1918, p. 1.

14 Sobre a mencionada lacuna nos estudos folclóricos maranhenses ver: Maria Laura de Viveiros de Castro Cavalcanti, "Por uma antropologia do folclore: o caso do Maranhão", in Sergio Ferreti e José Ricardo Ramalho (org.), Amazônia: desenvolvimento, meio ambiente e diversidade sociocultural (São Luis: EDUFMA, 2009) e Lady Selma Ferreira Albernaz. "O 'urrou' do boi em Atenas: instituições, experiências culturais e identidade no Maranhão" (Tese de Doutorado, Universidade de Campinas, 2004). A lacuna apontada pelos analistas nos "estudos sobre o folclore" maranhense deve-se ao fato de operar-se com uma concepção contemporânea de "cientificidade" e "pesquisa" que exclui toda produção literária ficcional de cunho regionalista inspirada nos estilos naturalistas e realistas produzida com esse fim. Entretanto, no período, as fronteiras entre literatura e pesquisa objetiva ainda não estavam tão demarcadas, quanto menos nesse campo. Ver Renato Ortiz, Românticos e folcloristas, São Paulo: Olho d'Água, 1992.
} 
sentação da identidade regional e nacional capazes de incluir negros, mestiços e caboclos na concepção simbólica do seu ethos. ${ }^{15}$

Não é possível dizer com precisão quando Astolfo Marques começou a redigir As festas populares maranhenses. Contudo, na contracapa do livro A vida maranhense (1905), encontra-se a indicação “As Festas Populares Maranhenses (Em preparação)". Na contracapa de $A$ nova aurora, oito anos depois, encontra-se uma referência um pouco diferente: "Em conclusão: As Festas Populares Maranhenses, narrativa histórica, I Vol.". Durante esse intervalo de tempo, o projeto se teria ampliado consideravelmente para compor uma obra com mais de um volume, sendo provável que o capítulo dedicado à festa de $\mathrm{S}$. Benedito pertencesse à fase em que o trabalho teria ganho sua forma mais definitiva. A indicação de um próximo volume para o livro e a não publicação do texto - "em conclusão" em 1913 - até 1918, ano de sua morte, sugerem que Astolfo Marques trabalhou no projeto até quando sua saúde o permitiu, somando ao todo, no mínimo, treze anos de pesquisa.

O título pretendido ao livro trai a influência do folclorista baiano Mello Moraes Filho e do seu estudo clássico Festas e tradições populares do Brasil. $\mathrm{O}$ autor é citado por Astolfo Marques entre suas referências no seu primeiro artigo conhecido acerca do cancioneiro maranhense no número de estreia da revista Os Novos, de 5 de agosto de 1900. Nesse pequeno artigo, Astolfo Marques apresenta as razões que justificam esse tipo de pesquisa:

Iniciamos hoje um modesto estudo sobre o folk-lore maranhense, cujas bases foram lançadas no Brasil pelo malogrado e talentosíssimo poeta, romancista e crítico Celso Magalhães, nosso inolvidável conterrâneo. Estas pesquisas depois foram continuadas, com mais ou menos acerto, pelos Srs. Koseritz, Sílvio Romero, Mello Moraes Filho e outros.

\footnotetext{
${ }^{15}$ A literatura e o jornalismo produzidos por intelectuais negros maranhenses como Nascimento Moraes (1882-1958), Viriato Correa (1884-1962) e o próprio Astolfo Marques, os quais pertenceram às principais instituições destinadas à produção, circulação e distribuição de bens simbólicos eruditos na Primeira República, podem se contrapor, no âmbito da historiografia maranhense, a uma perspectiva que demarca os anos 1900-1930 como de exclusão simbólica do "povo" na representação erudita da identidade regional como em Antonio Evaldo Almeida Barros, "O Pantheon encantado: culturas e heranças étnicas na formação de identidade maranhense (193765)" (Dissertação de Mestrado, Universidade Federal da Bahia, 2007) e Manuel de Jesus Barros Martins, Operários da saudade, São Luís: EDUFMA, 2006.
} 
Os focos originários do folk-lore são a Bahia e o Maranhão, devendo notar-se que o movimento comercial nesse tempo estabelecido entre os sertões dessas duas então províncias foi o mais sólido agente dessas relações. ${ }^{16}$

A primeira justificativa apresentada pelo autor para realização de seus estudos sobre cultura popular é a retomada da pesquisa científica do folclore nos termos firmados pelo poeta e crítico maranhense Celso Magalhães, a cujos trabalhos pretendia dar continuidade, tendo como objeto exclusivo o folclore maranhense. Com efeito, os estudos do "malogrado e talentosíssimo poeta" com o título "A poesia popular brasileira" publicados, em 1873, no jornal recifense $O$ Trabalho e, simultaneamente, em $O$ Domingo, na capital maranhense, são considerados o primeiro esforço de interpretação científica do folclore nacional. Morto aos 29 anos de idade, não pôde dar continuidade a suas investigações, entretanto, o amigo Sílvio Romero reuniu seus trabalhos em sua famosa antologia Estudos sobre cultura popular (1888), garantindo-lhe o reconhecimento nacional.

A segunda justificativa que ampara a necessidade de investigar a cultura popular maranhense é que o Maranhão e a Bahia são considerados, pelo autor, "os focos originários" do folclore brasileiro. Para ele, foram as relações comerciais distendidas ao longo dos sertões do norte agrário no período colonial que formaram a base das tradições populares brasileiras. Assim, o estudo do cancioneiro maranhense seria capaz de revelar aspectos do folclore nacional em suas formas mais originais e autênticas. É o mesmo ponto de vista de Mello Moraes no livro supracitado, particularmente nas primeiras linhas do capítulo "A Procissão de S. Benedito no Largato” em Sergipe, em que afirma:

De uma curiosidade, verdadeiramente rara e deleitável são os costumes do Norte, derivados de várias épocas da colônia, e ali transformados segundo condições múltiplas.

Quer se estude aquele povo em suas festas locais e religiosas, quer em sua vida íntima exterior, a sua fisionomia desenha-se de modo distinto, e relevo próprio o assinala, marcando-lhe um lugar saliente e à parte.

\footnotetext{
${ }^{16}$ Astolfo Marques, "O cancioneiro maranhense", Os Novos, n. 1 (1900), p. 1.
} 
[...] Assim, quem perlustrasse aquelas províncias, quem habitasse aquelas cidades e povoados, ora decadentes, veria que o povo tomava parte em todos os acontecimentos da vida nacional, e aparecia como individualidade representativa no que o país possuía de original e autônomo. ${ }^{17}$

O estudo das tradições populares também se justifica por nos permitir flagrar um período histórico, entendido como a época colonial, e um momento ritual, o próprio presente do observador das festas, nas quais o povo ascende como uma "individualidade representativa", influindo em todos os aspectos da vida nacional. ${ }^{18} \mathrm{~A}$ influência dessa perspectiva nos trabalhos de Astolfo Marques, escritos durante as primeiras décadas do regime republicano, esclarece por que, no seu trabalho literário e histórico, a crítica política aos limites da república de 1889 está entrelaçada às pesquisas das festas e tradições populares, nas quais a cena pública está tomada pelo povo. Nos termos dos valores políticos modernos difundidos pelo mundo na "Era das Revoluções", temos que o desconforto com os significados da liberdade conquistada na abolição e a igualdade prometida pela república aliam-se a um profundo investimento na fraternidade, isto é, nas festas enquanto momento extático capaz de abolir e questionar as diferenças e desigualdades sociais e raciais presentes no cotidiano. ${ }^{19}$

As escolhas, seleções e análises reunidas pelo autor para compor o capítulo "A festa de S. Benedicto" estão imbuídas dessa perspectiva. Na sessão "A devoção no Maranhão", muito da beleza que atribui à procissão do "Santo prêto" é que naquele dia tanto "As carruajens rodam celeres pela cidade", quanto "os bondes tranzitam apinhados". Por um lado, "Os melhores trajes sáem dos guarda-roupas e são cerimoniozamente envergados pela burguezia"; ${ }^{20}$ por outro, "O mercador, o car-

\footnotetext{
17 Mello Moraes Filho, Festas e tradições populares no Brasil, Belo Horizonte/Rio de Janeiro: Itatiaia, 1999, p. 69

18 Para maiores informações sobre a obra de Mello Moraes Filho, ver Martha Abreu, "Mello Moraes Filho: festas, tradições populares e identidade nacional", in Sidney Chaloub e Leonardo Pereira (org.), A história contada (Rio de Janeiro: Nova Fronteira, 1998).

19 Antonio Sergio Guimarães, “A República de 1899: utopia de branco, medo de negro (a liberdade é negra; a igualdade, branca e a fraternidade, mestiça)", Contemporânea, n. 2 (2011), pp. 17-36.

20 Astolfo Marques, “A festa de S. Benedicto", Diário do Maranhão, 02/04/1910, p. 2.
} 
roceiro, o carregador ambulante, os caboclos, que habitam no interior da Ilha, o barqueiro, o pescador" seguem para cumprir suas promessas. ${ }^{21}$ Para Astolfo Marques, naquele dia sagrado, todos caminham juntos, e o "alarido que parte daquele desordenamento, pela aglomeração" representa uma "toada sagrada e imponente, sublime e primitiva, o sentir do coração popular", pulsando em "glorioza harmonia". ${ }^{22}$

No tópico "As alforrias", o autor afirma ser a irmandade de S. Benedito a primeira instituição abolicionista no Maranhão. "A irmandade, composta primitivamente, na sua maioria, de gente de côr e escravizada, instituiu, no ano de 1867 , por feliz lembrança e bela iniciativa do poeta maranhense dr. ANTONIO MARTINS RODRIGUES, as 'alforrias de S. Benedicto", concedidas anualmente, no dia da festividade, a "crianças do sexo feminino", costume findo com a promulgação da Lei do Ventre Livre em $1871 .^{23}$ Esse ponto do texto é importante, pois reafirma o caráter político da compreensão e da interpretação dos significados das festas populares.

De acordo com Astolfo Marques, inúmeros milagres eram atribuídos "ao gloriozo Santo, no Maranhão", ${ }^{24}$ mas coube ao escritor narrar longamente apenas o que sucedeu com um capitão-geral, governador do Maranhão. Ao assistir a passagem da Procissão de Cinzas, ele estranhou "que o santo varão de Palermo, sendo de côr prêta, precedêsse na ordem procissional os demais santos, que eram brancos, e determinou que o colocassem em ultimo logar". Segundo consta, logo a seguir, o governador "foi acometido de fortissima febre" e "surgiu-lhe um antraz", passando a correr "sério perigo". O povo maranhense interpretou o ocorrido como "um castigo do céu" pelo seu desrespeito ao santo de cor preta. O capitão-geral, de boa vontade, não só pediu perdão pela desfeita, como fez uma promessa a S. Benedito, gesto que, segundo a tradição, privou-o da morte. ${ }^{25}$

Para Astolfo Marques, nas tradições populares de um povo, está

\footnotetext{
${ }^{21}$ Astolfo Marques, "A festa de S. Benedicto", Diário do Maranhão, 04/04/1910, p. 2.

22 Astolfo Marques, "A festa de S. Benedicto", Diário do Maranhão, 02/04/1910, p. 2.

${ }_{23}$ Astolfo Marques, "A festa de S. Benedicto", Diário do Maranhão, 04/04/1910, p .2.

${ }^{24}$ Astolfo Marques, "A festa".

25 Astolfo Marques, "A festa de S. Benedicto", Diário do Maranhão, 05/04/1910, p.2.
} 
presente a memória viva de suas lutas e desafios. Parte dos dilemas com que o autor se debateu na periferia da república brasileira era como arrastar o peso dessa história para dar sentido ao conceito de cidadania. De qualquer forma, restava-lhe a utopia de que, aos pés de um "Santo prêto", capaz de curvar governadores, senhores e escravos, negros e brancos, burgueses e carroceiros, homens e mulheres, juntos na paixão de uma só fé, talvez fosse possível uma nação. 
A FESTA DE S. BENEDICTO*

(Capitulo dum livro em preparação-

AS FESTAS POPULARES MARANHENSES).

\section{O culto}

É simples e tocante a historia de S. Benedicto, o milagrozo santo que dá orijem a uma das mais populares e pompozas festas do Maranhão.

Ha na dioceze da cidade italiana de Messana uma aldeia denominada S. Filadelfo e posteriormente apelidada San Fratello. Foi nella que teve o bêrço S. Benedicto, o Santo prêto, assim chamado por cauza de sua côr parecida com a dos etiópios. Os seus pais professavam a relijião católica, embora fosse [sic] oriundos de familias mouras e, portanto, impias.

Desde tenra idade Benedicto mostrava o mais fervoroso culto pelas coizas santas e, chegando á idade preciza para poder entrar a viver em comunidade, vendeu todos os seus haveres, distribuiu o produto pelos necessitados e foi rezidir com uns varões que, competentemente autorizados, viviam reunidos, sob a regra de S. Francisco de Assiz. Aí levou uma vida de santidade e fervor, até aos quarenta anos.

O papa Pio IV reuniu os solitarios, aos quais Benedicto acompanhava, a uma das ordens anteriormente aprovadas.

Em Palermo, a capital da Sicilia, domiciliou se Benedicto, que entrou para o convento de Santa Maria de Jesus e nelle, como na solidão, foi venerado por todos os relijiozos, pela sua doçura e inimitavel santidade. E o influxo de sua virtude era tal que, sendo ainda leigo, foi elle eleito prelado do mesmo convento.

O santo varão siciliano, com os seus saudaveis exemplos, plantou a reforma, que então começava a insinuar se, encaminhado-a para a completa perfeição.

Benedicto morreu a 4 de abril de 1589 , na idade de setenta e trez

*Diário do Maranhão, 02/04/1910, p. 2. 
anos, deixando os mais irrefragaveis exemplos de merecimentos e virtudes.

O seu corpo "permanece ainda completo em Palermo e exala delicado cheiro".

Estende se muitissimo o culto de S. Benedicto com a aprovação da Santa Sé, outorgada em 1774, fixando se, a sua festa em 3 de abril.

O gloriozo santo foi canonizado no ano de $1807^{(1)}$.

\section{A devoção no Maranhão}

Remonta a mais de século a devoção de S. Benedicto, no Maranhão, precedendo de muitos anos a data da sua canonização o que nada tem de estranhavel, pois, como acima ficou dito, a veneração pelo popular santo vem dos tempos em que elle praticava toda a sorte de virtudes e distribuia milagres ás mancheias, na capital siciliana.

A lei provincial n. 405 - de 27 de agosto de 1856, aprovou o compromisso por que ainda se reje a irmandade do gloriozo S. Benedicto, eréta na igreja do antigo convento dos relijiozos de Santo Antonio, em S. Luíz.

Havendo sido decretada pela Assembléa Provincial e sancionada, nos termos do art. 19 da carta de lei [de] 12 de agosto de 1834, não foi publicada no tempo legal a lei, pelo que o Barão de Coroatá a promulgou, na qualidade de prezidente daquella camara dos representantes.

Esse compromisso fôra aprovado pelo bispo D. Manuel. É este o respetivo termo de Provizão:

"D. Manuel Joaquim da Silveira, por mercê de Deus, e da Santa Sé Apostolica, Bispo do Maranhão, do Conselho de Sua Majestade o Imperador, comendador da Ordem de Christo, etc. etc, etc. - Aos que a prezente Nossa Provizão virem saúde e bençam - Fazemos saber que sendo - Nos aprezentado, em conformidade da lei de 27 de setembro

\footnotetext{
(1) N. do A.: Esta narrativa foi escrita resumidamente, para ser publicada no $1 .^{\circ}$ centenário da canonização de S. Benedicto (3 de abril de 1907). Tendo, porém, rezolvido completa-la para formar parte integrante do livro acima citado, conservamo-la inédita. - A. $M$. 
de 1828 , o prezente compromisso da irmandade de S. Benedicto desta cidade, e constando-nos que não se continha nos onze capitulos, oitenta e nove artigos e oitenta e um paragrafos, de que elle se compõe, couza alguma contra os bons costumes, doutrina da Santa Igreja, sua sagrada disciplina, e direito episcopais e paroquiais; havemos por bem de aprova lo, como pela prezente nossa Provizão o aprovamos, na parte que nos pertence, afim de só poder executar e praticar publicamente na egreja do convento dos relijiozos de Santo Antonio desta cidade, para honra e gloria de Deus Nosso Senhor, que tão louvavelmente se propõem e se devem propor com todo o zêlo os irmãos da referida irmandade. Dada nesta cidade de São Luiz do Maranhão, sob nosso sinal, chancelaria, e sêlo de nossas armas, aos 7 de julho de 1854. E eu, o conego arcipreste Candido Pereira de Lemos, secretario do bispado e da camara episcopal que a subscrevi (Assinado) † Manuel, Bispo da [sic] Maranhão".

A irmandade instituida para o serviço e culto do gloriozo S. Benedicto tem como confrades pessoas de ambos os sexos, de qualquer condição que, sendo de costumes relijiozos e honestos, queiram, por sua devoção, concorrer com os seus bons serviços para maior esplendor do culto do seu patrono, e possúe prezentemente não pequeno patrimonio, honestamente zelado.

A joia de admissão é de um mil rèis, e a anuidade, primitivamente de duzentos reis, está hoje fixada em quinhentos.

Tem a irmandade a seu encargo festejar o santo, com toda a pompa e explendor, no Domingo da Pascoèla, precedendo se de triduo o dia da festa. Os festejos são internos e externos e a elles acorre toda a população. A missa da festa tem a mais estupenda assistencia e a igreja de Santo Antonio, eréta na sua elegancia gotica, apezar de ser uma das maiores da capital maranhense é pequena para contê-la.

Mas o que constitue a nota primaria dos festejos é, sem dúvida, a procissão, para a qual desde o alvorecer começa a movimentação. Nesse dia, a cidade amanhece toda alvorotada.

S. Luiz canta na voz, nas epopéas dos sinos de Santo Antonio, feridos num resoamento santo e evocador. No campanario, o longo e alegre bimbalhar da sinarada sôa incessantemente, enquanto o foguetório estalida com fragor. 
As carruajens rodam celeres pela cidade e os bondes tranzitam apinhados.

Os melhores trajes sáem dos guarda-roupas e são cerimoniozamente envergados pela burguezia.

Tudo nesse dia se move, se alinda e rejuvenece.

Aproximando-se as horas da saída da procissão, sempre ás cinco da tarde, começa a aglomerar se, no templo e no largo, a multidão, avolumando-se á proporção que o cortêjo se vai organizando.

É uma rumoroza turba - homens e mulheres, velhos e crianças, familias inteiras com petizes e criados, tudo a formar um quadro pinturesco. Vestes de todas as côres, claras e escuras, a cintilação do oiro dos agalobados, as velas enfeitadas a fumegar numa crepitação incessante, o reluzir dos enfeites, formando, no conjunto um aspéto feérico.

Os irmãos sucedendo se, com as suas opas pardas, o alarido que parte daquelle dezordenamento, pela aglomeração, é, numa toada sagrada e imponente, sublime e primitiva, o sentir do coração popular. Empurrões, acotovelamentos, pizadas, todo esse clangor se caza em glorioza harmonia.

Astolfo Marques.

(A seguir). 
A FESTA DE S. BENEDICTO*

(Capitulo dum livro em preparação-

AS FESTAS POPULARES MARANHENSES).

(Continuação)

A procissão segue.

De todos os cantos de ruas e praças surje gente em numero elevado, incorporando se a ella, de modo que, dado o giro respetivo, ao recolher se, já ao cair da tarde, a compata massa popular que constitue a imponente procissão não é inferior a uma dezena de milhar de pessoas.

$\mathrm{E}$, ao recolher-se o cortejo, o largo ilumina-se fartamente. A decoração com que o revestem resalta galharda e é atravéz essa ornamentação cheia de esmero que a população se distende até o momento da queima dos fogos, o elemento mais predominante nas festas de arraial, no Maranhão.

No dia seguinte ao da procissão, "segunda-feira de S. Benedicto", ainda ha festa. Esse dia dos frios ou lava-pratos, é ainda relijiozamente guardado como o anterior. Os operarios fazem suéto e, em traje domingueiro, passeiam e embrenham-se nos folguedos pela cidade. É também um dia muito escolhido pelas familias para vizitas, fazendo as quaze sempre ao regressar da missa que se celebra no andor do santo, ás 7 horas, com uma assistencia espantoza.

\section{As promessas}

Dificilimo torna-se de calcular o numero de promessas que os fieis pagam, na prosissão. Uns fazem-se acompanhar de crianças, vestidas de anjos, em numero que excede de um milhar, sem exajero; outros conduzem á cabeça, durante o giro do cortejo, pedras, pedaços de madeira, potes ou canecos com agua ou quaes quer outros objétos de variados tamanho.[sic] Ha tambem prometentes que comparecem caprichozamente trajados, porém descalços. São sem conta os que se incorporam á

\footnotetext{
Diário do Maranhão, 04/04/1910, p. 2.
} 
procissão, levando velas de cêra, enfeitadas ou não, as quais, acezas, confundem-se com os cirios conduzidos pelos irmãos.

Existe um costume de promessa algo curiozo, muito arraigado entre a população. É crença geral de que as mulheres, tendo consecutivamente filhos nati-mortos, os nascidos ulteriormente vingarão, se se lhes puzer o nome de Benedicto ou Benedicta, conforme o sexo, dando os pais, na primeira procissão apoz o nascimento da criança, um anjo para acompanha la. Esse voto só é concluido, em definitivo, quando a criança se encontra em idade de de [sic] comparecer ella propria trajada de anjo.

O mercador, o carroceiro, o carregador ambulante, os caboclos, que habitam no interior da Ilha, o barqueiro, o pescador, podem não possuir um real para quasquer gastos, mas é muito duvidozo que não o obtenham, apoz o mais insano e esfalfante trabalho, para entonar-se e adquirir uma vela de cêra, de uma libra que seja, e ir depozita-la aos pés do Santo varão, no seu altar ou, ainda, vestir de anjo (cativo ou fôrro) uma criança e leva-la a tomar parte entre a multidão que acorre a formar a suntuoza procissão.

$\mathrm{E}$, assim, todos pagam a sua promessa, todos cumprem o seu voto.

\section{As alforrias}

Foi a festividade de S. Benedicto um dos primeiros campos em que teve ação, na provincia, o movimento abolicionista.

A irmandade, composta primitivamente, na sua maioria, de gente de côr e escravizada, instituiu, no ano de 1867, por feliz lembrança e bela iniciativa do poeta maranhense dr. ANTONIO MARQUES RODRIGUES, as "alforrias de S. Benedicto", as quais consistiam na libertação de crianças do sexo feminino, todos os anos, no dia da festa.

Aquelle pranteado abolicionista e fervorozo cantor do escravo, aceitando o juizado da festa, no citado ano fê-lo com a condição de tornar a sua meritoria idéa uma bandeira, pela qual a irmandade se batesse ardorozamente, o que foi cumprido com rara pertinacia, sem o menor dezanimo. 
E nos anos subsequente [sic] o beneficio repetia-se, cada vez mais aproveitando a [sic] maior numero de crianças. Era aproximar-se a época da festividade, e lá o condoreiro saía com os irmãos do popular e milagrozo Santo, para angariar os meios de promover a libertação dos pequeninos, deparando-se-lhe nessa bendita romaria não diminuta soma pecuniaria, com que se alforriavam dezenas de crianças.

Adoecendo gravemente, MARQUES RODRIGUES teve de partir para a Europa; deixou, porém, o seu sogro e tio Joaquim Marques Rodrigues encarregado de proseguir na sua filantropica e arrojada tarefa.

E isso se cumpriu atè 1871, quando se promulgou a Lei Rio Branco ou do Ventre Livre.

$\mathrm{Na}$ festa do ano seguinte, [a] irmandade numa homenajem sincera e enobrecedora, inaugurou pompozamente no seu consistorio, o retrato a oleo de diréto instituidor dos "alferrias [sic] de S. Benedicto", retrato que ali tem sido relijiozamente conservado.

\section{Os milagres}

Inumeros são os milagres atribuidos ao gloriozo Santo, no Maranhão, correndo de bôca em bôca com esse amor sincero e transbordante ao tradicionalismo, que se entranha indestrutivelmente na alma popular, num culto cujo fervor não decresce, ao contrario aumenta de ano para ano.

Dentre esses milagres, o que mais se avulta traspassando de geração em geração, é o que deu orijem á interessante historia da Capa nova, sem dúvida um dos élos que mais fortemente prendem essa corrente una de devoção e amor acrizolado com que a população maranhense se apega a S. Benedicto, historia que é amiudamente contada nos serões, maximé entre a população inferior de certo a possuidora de maior crença e em cujo seio mais ardentes e vivos se aninham os sentimentos de Fé.

Astôlfo Marques.

(A seguir). 


\section{A FESTA DE S. BENEDICTO*}

(Capitulo dum livro em preparação-

AS FESTAS POPULARES MARANHENSES).

(Concluzão)

Um capitão-general, governador do Maranhão, fôra assistir, da janela duma caza no antigo largo do Carmo, a passajem da Procissão de Cinzas, com a qual se iniciavam, na capital maranhense, as ceremonias quaresmais.

Nesse cortejo, que saía da mesma igreja conventual de Santo Antonio, na Quarta-feira de Cinzas, e era composto de uma dezena de santos, figurava em primeiro escalão o andor com a imajem de S. Benedicto.

Estranhou o general que o santo varão de Palermo, sendo de côr prêta, precedêsse na ordem procissional os demais santos, que eram brancos, e determinou o colocassem em ultimo logar, resolução que se cumpriu incontinenti, proseguindo a procissão no seu giro.

Ao regressar ao palacio do governo, o general foi acometido de fortissima febre e, no dia seguinte, surgiu-lhe um antraz. Os facultativos, que acudiram ás pressas, responderam que a vida do governador corria sério perigo.

A noticia propalou se celeremente.

Esperava-se a todo o momento o dezenlade fatal.

O povo, atemorizado, via na repentina enfermidade do chefe do governo um castigo do céu, uma reprenmida ao seu procedimento, á sua descrença das coizas santas, alterando, sem razão plauzivel, o que já era consagrado pelo sentimento relijiozo.

E a grita estendeu-se por toda a cidade, a incriminação crescendo de instante a instante.

A esse tempo, o ajudante d'ordens do capitão-general, dandolhe conta do dezagrado em que elle incorrêra entre o povo, induziu-o a pedir perdão ao santo ultrajado.

\footnotetext{
* Diário do Maranhão, 05/04/2010, p. 2.
} 
O enfermo, querendo dezenvencilhar-se dos tormentos que, pela sua gravidade, o impeliam já para as portas da morte e receiando, tambem, um levante da população catolica, não só pediu de boa vontade o perdão como fez mais ainda: Prometeu, que, se se restabelecesse, faria vir da Europa uma capa riquissima, afim de que S. Benedicto se revestisse para com ella saír na proxima procissão, a qual seria feita ás suas expensas.

O milagre não se fez esperar. A saúde tornou ao organismo do governador, na sua plenitude e, tempos depois, da Europa chegava a riquissima capa. Mas nem elle nem os seus parentes lograram ver o santo saír com a capa que, conforme a promessa, lhe fôra ofertada; pois, todas as vezes que o revestiam com a capa-nova, a chuva se desprendia grossa e torrencial, e a procissão não se realizava.

Então, a irmandade rezolveu arquivar o prezente, tacitamente recuzado pelo seu patrono.

Mas a crença de que a condenada capa faz chover perdura ainda. Basta ameaçar chuva no dia da procissão para que, entre o povo se murmure logo, com certa convicção: "S. Benedicto está com a capa nova”!

A criança que ouve essa narrativa, tão freqüente nos serões, é também informada de outros milagres que, numa corrente interminavel são feitos pela crendice popular. Sabe o quanto era prodijioza a distribuição de milagres que consecutivamente o santo ciciliano operava em Palermo, principalmente no exercicio de suas funções culinárias.

Entré elles, conta-se com especial destaque, que Benedicto, enviando clandestinamente, aos pobres, viveres do mosteiro, foi surpreendido pelo superior que, indagando do conteúdo do volume, o leigo respondeu-lhe:

- São flôres, senhor ! E a comida surjiu transformada efetivamente em finissimas e odoriferas flores.

A santidade de que se revestiu a existencia do milagrozo santo e cujo èco se distendeu por todo o orbe terrestre, repercutiu portanto, vivamente no Maranhão. 


\section{A ramificação cultural}

Sem pretendermos afirmar que a mór parte dos fieis católicos tenha como real o epizodio que motivou a promessa do capitão general e o seu cumprimento, á risca, o que se não póde negar absolutamente é que, de ano para ano se comprova, cada vez mais crescente, o mais penetrante e fervorozo devotamento por S. Benedicto.

E esse ardente culto se não restrinje á capital. Não é sómente nella que é lindo e consolador contemplar, no dia da festividade, a cidade engalamada e toda alacre, extasiando se a gente em vê la, por entre aquelle gozo do prezente, parecerem olvidadas as agruras e desprezados os cuidados do porvir, mostrando-se todos felizes e contentes, unificados na entonação desse hino dulcissimo ao santo siciliano, ao milagrozo, ao popular, ao incessantemente venerado.

No interior maranhense é prodijioza a ramificação do culto, no seu entuziasmo vibrante e comunicativo.

Em Caxias, a cidade mais importante do Maranhão, depois da capital, a festa beneditina é a mais imponente e popular que ali se efetua, a ella afluindo devotos dos sitios circunvizinhos e até do proximo Estado do Piauhy. Nas cidades de Alcantara, Vianna e Tury-assú, nas vilas do Rosario e das Pedreiras, e em outras muitas localidades do interior do Maranhão, o sentimento relijiozo pelo santo, popular, amparado pelas gerações que se sucedem, aumenta carinhozo e sincero, sempre firme e inabalavel.

Por todos esses recantos da terra maranhense encontra-se, sob a invocação beneditina uma capela, com a silhouette de sua esguia torre a apontar para o céu o simbolo da devoção dos habitantes locais pelo milagrozo Santo.

A festa de S. Benedicto permanece, pois cada vez mais ruidoza e cheia de ponpa, a resaltar aos olhos dos crentes e descrentes o poder vigorozo imensuravel e indestrutivel antes das coizas tradicionais do que dum povo fanatizado.

Astôlfo Marques.

4-4-1910. 